\title{
METALLURGICAL EVALUATION OF THE HOIDAS LAKE RARE EARTH DEPOSIT
}

\author{
Corby G. Anderson ${ }^{1 *}$, Paul J. Miranda ${ }^{2}$ \\ ${ }^{I}$ Kroll Institute for Extractive Metallurgy, Colorado School of Mines Golden, \\ Colorado USA \\ ${ }^{2}$ Eagle Engineering Butte, Montana USA
}

Received 01.06.2020

Accepted 11.07.2020

\begin{abstract}
Hoidas Lake lies in the Northern Rae Geological Province, in the general vicinity of many of Saskatchewan's large uranium mines. The mineralogy of the Hoidas Lake rare-earth deposit differs from most other such deposits in that it is hosted in equal abundance in veins containing apatite and allanite mineral groups. Hoidas Lake also differs from other deposits in that it contains a significant amount of heavy rare-earth elements, such as dysprosium. This abundance of heavy Rare Earth Elements (REE's) is significant, as there is a growing demand for the heavier rare earths in high-tech manufacturing (such as the use of dysprosium in the manufacturing of hybrid car components). Recently, metallurgical testing was performed on a Hoidas Lake REE deposit composite. These investigations included characterization, flotation testing, heavy media separation, magnetic separation testing, whole ore leaching studies, bond work index grindability testing, and relative abrasion index testing. This paper summarizes this research effort.
\end{abstract}

Keywords: Hoidas Lake; Rare Earth Elements; deposit composite.

\section{Introduction}

Approximately 75 kilograms of Hoidas Lake material was crushed and blended into a composite. Subsequently, several metallurgical tests were performed on the Hoidas Lake composite. These investigations included flotation testing, heavy media separation, magnetic separation testing, whole material leaching studies, bond work index grindability testing, and relative abrasion index testing.

*Corresponding author: Corby G. Anderson,cganders@mines.edu 


\section{Mineralogy}

Sample characterization was also performed using thin section mineralogical examinations, X-Ray diffraction, ICP elemental analysis, sulfur, and carbon analysis and $\mathrm{SEM} / \mathrm{EDX}$ analysis. It was determined that the REE content was evenly divided in the two predominant host mineral groups of apatite, $\mathrm{Ca}_{5}\left(\mathrm{PO}_{4}\right)_{3}(\mathrm{~F}, \mathrm{Cl}, \mathrm{OH})$, and allanite, $(\mathrm{Ce}, \mathrm{Ca}, \mathrm{Y}, \mathrm{La})_{2}\left(\mathrm{Al}, \mathrm{Fe}^{+3}\right)_{3}\left(\mathrm{SiO}_{4}\right)_{3}(\mathrm{OH})$. No other REE bearing minerals of significance were found in the sample. This confirmed previous noted investigations where the diopside-allanite veins and apatite breccia veins of the Hoidas Lake light rare earth element (LREE) deposit in northern Saskatchewan, Canada, represent a complex magmatic-hydrothermal system unrelated to its strongly deformed Archean and Paleoproterozoic host rocks in the Rae sub province [1]. The veins were emplaced along the Hoidas-Nisikkatch fault, a subsidiary of the deeply rooted Black Bay fault system, which likely provided pathways for the melts and fluids. Allanite in the diopside-allanite veins is concentrically zoned, reflecting rare earth element (REE) depletion, followed by REE enrichment. Later apatite breccia veins comprise multiple apatite generations. Graphic-textured inclusions in the earliest red apatite indicate the presence of a melt during apatite growth. The average total rare earth oxide (TREO) content increases from 1.5 wt. $\%$ in the red apatite to 5.5 wt. $\%$ in the green apatite, both dominated by Ce. In contrast, the latest generation, coarse red apatite, contains about $1 \mathrm{wt} . \%$ TREO and is $\mathrm{Nd}$ dominant. This shift from $\mathrm{Ce}$ - to Nd-dominant apatite might reflect a transition from magmatic to hydrothermal growth. Interaction with hydrothermal fluids resulted in chlorite-hematite alteration and REE redistribution into secondary monazite, REE carbonates, REE-Sr carbonates, and allanite, the last occurring in late quartz-carbonate veins and containing up to 32.9 wt. \% TREO. The chemistry of the REE-bearing phases and their connection with hyalophane-bearing pegmatites and later lamprophyre dikes indicate a mantle-derived, most probably carbonatitic or syenitic source for the mineralizing melts and fluids.

\section{Rare earths research at KIEM}

Rare Earths, sometimes called the vitamins of modern materials, captured public attention when their prices increased more than ten-fold in 2010 and 2011 [2-8]. As prices fell between 2011 and 2016, rare earths receded from public view-but less visibly they became a major focus of innovative activity in companies, government laboratories and universities. Geoscientists worked to better understand the resource base and improve our knowledge about mineral deposits that will be mines in the future. Process engineers carried out research that is making primary production and recycling more efficient. Materials scientists and engineers searched for substitutes that will require fewer or no rare earths while providing properties comparable or superior to those of existing materials. As a result, even though global supply chains are not significantly different now than they were before the market disruption, the innovative activity motivated by the disruption likely will have far-reaching, if unpredictable, consequences for supply chains of rare earths in the future.

At the Kroll Institute for Extractive Metallurgy (KIEM), extensive studies have been undertaken in the treatment of rare earth ores and recycled materials with a focus on beneficiation and hydrometallurgy [9-15]. Much of this research has been undertaken through the DOE Critical Materials Institute hub. The Critical Materials Institute (CMI) focuses on technologies that make better use of materials and eliminate the need for 
materials that are subject to supply disruptions. These critical materials are essential for American competitiveness in clean energy. Many materials deemed critical by the U.S. Department of Energy are used in modern clean energy technologies, including wind turbines, solar panels, electric vehicles, and energy-efficient lighting.

\section{Bastnaesite REE's}

Bastnaesite beneficiation by gravity and flotation have been studied at KIEM [1622]. Flotation separation of bastnaesite from carbonate gangue has proved to be an exceedingly difficult task. Yet it remains the dominant unit operation for beneficiation of rare earth element-bearing minerals. The high specific gravity of these minerals (bastnaesite and monazite) in relation to the gangue (calcite) suggests the opportunity for beneficiation through gravity separation. The purpose of this investigation was to determine the applicability of centrifugal concentrators to the beneficiation of a bastnaesite ore from the Mountain Pass mine containing large amounts of calcite gangue. Heavy media separation, MLA Analysis, and a Falcon Concentrator were used to show the amenability of this ore to gravity separation. From a feed averaging $12 \%$ calcium, $6.7 \%$ barium, and $3.4 \%$ rare earth elements (lanthanum, cerium, praseodymium, samarium, and neodymium), an optimum product of $14.5 \%$ calcium, $13.13 \%$ barium, and $7.8 \%$ rare earth elements was generated using the longest grinding time, lowest feed rate, and lowest G-force.

Many fundamental studies have been done using hydroxamates, fatty acids, and phosphoric acids as collectors to selectively float bastnaesite. The focus of some KIEM current research is to find an economically viable collector that provides selectivity of bastnaesite over its gangue minerals such as calcite. The fundamental studies included mineralogical characterization, adsorption density, zeta potential, micro flotation, and bench flotation. Recently, a suite of novel flotation collectors has been delineated with micro flotation and subsequent verification by bench and pilot scale testing to greatly enhance the rougher flotation of bastnaesite in terms of concentrate grade and recovery while separating away over $90 \%$ of the deleterious calcite gangue.

\section{Xenotime REE's}

In Xenotime flotation at studies [23-25] at KIEM, a pre-concentrated xenotime sample and four selected gangue minerals, ilmenite, zircon, schorl and staurolite were used. Using octano-hydroxamic acid as a collector, the surface chemistry was investigated through surface area measurements, zeta potential tests and adsorption density determinations. The results of adsorption studies were then correlated with micro flotation tests conducted at room temperature in a Partridge-Smith cell. In this study, the surface chemistry and micro flotation behaviors were discussed based on both lab observations and a literature review.

Because of their selective depressing power, sodium silicate and lignosulfonate have been widely used as depressants in rare-earth mineral flotation to separate minerals from specific types of gangue minerals. In this project, flotation of a xenotime preconcentrate and pure samples of gangue ilmenite, zircon, schorl and staurolite using octano-hydroxamic acid and sodium oleate as collectors was conducted in a PartridgeSmith micro flotation cell. The flotation of the mixed samples (weight ratio=1:1) of xenotime and each one of its gangue minerals was also investigated at room temperature and $80^{\circ} \mathrm{C}$, using sodium silicate and ammonium lignosulfonate in the presence of octanohydroxamic acid and sodium oleate, respectively. The flotation results are described and 
compared with those observed by previous researchers. The effects of sodium silicate and ammonium lignosulfonate on weight recoveries and the grade of xenotime are also discussed and compared.

\section{Monazite REE's}

Monazite flotation has been studied at KIEM [26, 27]. Monazite is the second most important rare earth mineral that can be further exploited. In this study, the surface chemistry of monazite in terms of zeta potential, adsorption density, and flotation response by micro flotation using octanohydroxamic acid is determined. Apatite, ilmenite, quartz, rutile, and zircon are minerals that frequently occur with monazite among other minerals, hence were chosen as gangue minerals in this study. The Iso Electric Point (IEP) of monazite, apatite, ilmenite, quartz, rutile, and zircon are 5.3, 8.7, $3.8,3.4,6.3$, and 50.1 respectively. The thermodynamic parameters of adsorption were also evaluated. Ilmenite has the highest driving force for adsorption. Adsorption density shows that hydroxamate adsorbs on to monazite and its gangue minerals. This observation was further confirmed by micro flotation experiments. Increasing temperature to $80^{\circ} \mathrm{C}$ raises the adsorption and floatability of monazite and gangue minerals, which does not allow for separation. Appropriate use of depressants is recommended to achieve separation of monazite from its gangue.

\section{Ancylite REE's}

The Bear Lodge Project is an important rare earth deposit in the United States [2833]. KIEM has investigated the recovery of rare earths from this deposit. Ancylite, a strontianite rare earth carbonate, is a significant source of rare earth bearing minerals at Bear Lodge. In this research, essential aspects of the magnetic separation and flotation processes are presented. Based on an optimization of the variables and flotation simulation, a flowsheet was proposed. Furthermore, the economic feasibility for obtained processing conditions was analyzed. While extensive testing has settled on a crushing, screening, gravity and magnetic separation process, this study sets out to investigate an alternative flowsheet based on flotation and wet high intensity magnetic separation (WHIMS) to effectively beneficiate the rare earth oxide (REO) content of the Bear Lodge ore. Mineral characterization found ancylite was the dominant rare earth mineral, associated mainly with calcite and strontianite. Zeta potential studies indicated that the

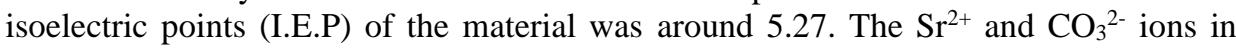
solution significantly affected the surface change of the material. Hydroxamic acid, used as the collector, was chemically adsorbed onto the surface of the material, which was confirmed by both zeta potential and adsorption tests. WHIMS was employed to remove the iron content to reduce the interference of iron in following the flotation process and consumption of hydroxamic acid. After cleaner flotation, a REO grade of $11.2 \%$ at $72.7 \%$ recovery from a feed material of $4.5 \%$ REO was obtained. Overall REO grade of $11.2 \%$ at $61.2 \%$ recovery was achieved compared to the previous grade of $6.64 \%$ at $86.4 \%$ recovery from similar feed grade material.

\section{Eudialyte REE's}

Beneficiation and hydrometallurgical treatment of eudialyte from Norra Karr has been researched at KIEM [34-36]. The Norra Karr project in Sweden was undertaken by Tasman Metals Ltd., in consultation with ANZAPLAN, with the intention for determining the most suitable beneficiation route for the Norra Karr mineralized material. 
Different techniques were investigated, such as spiral concentration, electrostatic separation, high-G separation, magnetic separation, and froth flotation. Results showed that aegirine could be selectively floated, but the co-flotation of non-liberated particles concluded that a direct flotation of eudialyte would be unsuccessful. Recovery values were recorded for eudialyte via WHIMS, but with no significant upgrade in the rare earth concentration.

The literature survey regarding eudialyte beneficiation experiments indicate that at least a multiple step process is necessary for the separation of the eudialyte mineral from its gangue components. At present, at KIEM, physical rejection of iron followed by sulfuric acid leaching appears to be a tangible approach allowing enhanced rare earth and zirconium recoveries while minimizing the process impacts of iron gangue.

Apatite REE's

A review of REE's deportment in apatite has recently been completed [37]. Apatite can substitute up to half the elements within the periodic table into its structure, and as such can become enriched with several different elements during either formation or a later hydrothermal alteration. Enrichment and alterations can be used to reflect early environments, from geological processes to early sea temperatures and paleo environments. Sometimes the enrichment of a particular element makes the apatite of interest for that enrichment alone; for example, in Songwe Hill Malawi, apatite enriched with REE is under development as a REE mine.

\section{Hoidas lake deposit composite testing}

\section{Composite Material Preparation}

The initial scope of work included composite preparation of a received sample. Initially, the sample was crushed to less than $1 / 2$ " using a jaw crusher and further crushed to 100 percent passing 6 mesh using a roll crusher. The 75 kilograms were then split to 75, 1-kilogram samples using the Jones Splitter. From this split, a 1 kilogram of sample was used for the head analysis that is shown in Tables 1 through 3.

Table 1. Rare Earth Element ICP Analysis.

\begin{tabular}{lll|lll}
\hline \multicolumn{5}{l}{ Hoidas Lake Bulk Composite - Rare Earths Analysis } \\
Element & Name & $\%$ & Element & Name & $\%$ \\
\hline TREE & \multicolumn{1}{l}{ Total Rare Earth Elements } & & & \\
$\mathrm{La}$ & Lanthanum & 0.249 & $\mathrm{Dy}$ & Dysprosium & 0.00394 \\
$\mathrm{Ce}$ & Cerium & 0.678 & $\mathrm{Ho}$ & Holmium & 0.00093 \\
$\mathrm{Pr}$ & Praseodymium & 0.0959 & $\mathrm{Er}$ & Erbium & 0.00188 \\
$\mathrm{Nd}$ & Neodymium & 0.389 & $\mathrm{Tm}$ & Thulium & ND \\
$\mathrm{Pm}$ & Promethium & $\mathrm{NA}$ & $\mathrm{Yb}$ & Ytterbium & 0.0007 \\
$\mathrm{Sm}$ & Samarium & 0.0648 & $\mathrm{Lu}$ & Lutetium & 0.0002 \\
$\mathrm{Eu}$ & Europium & 0.013 & $\mathrm{Sc}$ & Scandium & 0.0007 \\
$\mathrm{Gd}$ & Gadolinium & 0.023 & $\mathrm{Y}$ & Yttrium & 0.0248 \\
$\mathrm{~Tb}$ & Terbium & 0.0029 & & & \\
\hline
\end{tabular}


Table 2. Whole Rock ICP Analysis.

\begin{tabular}{llc}
\hline Hoidas Lake Bulk Composite - Whole Rock Analysis \\
Element & Name & $\%$ \\
\hline $\mathrm{Al}_{2} \mathrm{O}_{3}$ & Aluminum Oxide & 2.909 \\
$\mathrm{CaO}$ & Calcium Oxide & 24.22 \\
$\mathrm{Fe}_{2} \mathrm{O}_{3}$ & Iron Oxide & 3.181 \\
$\mathrm{~K}_{2} \mathrm{O}$ & Potassium Oxide & 0.800 \\
$\mathrm{MgO}$ & Magnesium Oxide & 2.984 \\
$\mathrm{Na}_{2} \mathrm{O}$ & Sodium oxide & 0.480 \\
$\mathrm{P}_{2} \mathrm{O}_{5}$ & Phosphate & 7.030 \\
$\mathrm{TiO}_{2}$ & Titanium Oxide & 0.156 \\
$\mathrm{SiO}_{2}$ & Silica & 15.66 \\
$\mathrm{LOI}$ & Loss On Ignition & 2.01 \\
\hline
\end{tabular}

Table 3. ICP Detailed Analysis Elemental Scans.

\begin{tabular}{lll|lll}
\hline \multicolumn{5}{c}{ Hoidas Lake Bulk Composite - Detailed Analyses } \\
Element & Name & $\%$ & Element & Name & $\%$ \\
\hline $\mathrm{Ag}$ & Silver & 0.000038 & $\mathrm{Mo}$ & Molybdenum & 0.00041 \\
$\mathrm{As}$ & Arsenic & 0.00679 & $\mathrm{Ni}$ & Nickel & 0.00129 \\
$\mathrm{Au}$ & Gold & $\mathrm{ND}$ & $\mathrm{Pb}$ & Lead & 0.00724 \\
$\mathrm{~B}$ & Boron & 0.000845 & $\mathrm{~S}$ & Sulfur & 0.219 \\
$\mathrm{Ba}$ & Barium & 0.61 & $\mathrm{Sb}$ & Antimony & 0.00168 \\
$\mathrm{Be}$ & Beryllium & 0.00041 & $\mathrm{Se}$ & Selenium & $\mathrm{ND}$ \\
$\mathrm{Co}$ & Cobalt & 0.00125 & $\mathrm{Sn}$ & Tin & 0.0648 \\
$\mathrm{Cr}$ & Chromium & 0.00234 & $\mathrm{Sr}$ & Strontium & 0.34 \\
$\mathrm{Cs}$ & Cesium & $\mathrm{ND}$ & $\mathrm{Ta}$ & Tantalum & 0.00085 \\
$\mathrm{Cu}$ & Copper & 0.00914 & $\mathrm{Te}$ & Tellurium & 0.00188 \\
$\mathrm{Ga}$ & Gallium & $\mathrm{ND}$ & $\mathrm{Th}$ & Thorium & 0.03 \\
$\mathrm{Hf}$ & Hafnium & 0.000091 & $\mathrm{Tl}$ & Thallium & $\mathrm{ND}$ \\
$\mathrm{Hg}$ & Mercury & 0.000053 & $\mathrm{U}$ & Uranium & $\mathrm{ND}$ \\
$\mathrm{I}$ & Iodine & $\mathrm{ND}$ & $\mathrm{V}$ & Vanadium & 0.00553 \\
$\mathrm{In}$ & Indium & $\mathrm{ND}$ & $\mathrm{W}$ & Tungsten & 0.00343 \\
$\mathrm{Ir}$ & Iridium & $\mathrm{ND}$ & $\mathrm{Zn}$ & Zinc & 0.0117 \\
$\mathrm{Li}$ & Lithium & 0.00301 & $\mathrm{Zr}$ & Zirconium & 0.00417 \\
$\mathrm{Mn}$ & Manganese & 0.086 & & & \\
\hline
\end{tabular}

\section{Flotation testing}

Two flotation experiments were performed on the composite which produced a rougher concentrate, a scavenger concentrate, and the final tails. The tests differed by collectors used. The initial test used fatty acid and tall oil collectors while the second test used fatty acid and petroleum sulfonate collectors.

The experimental test charges used one kilogram of the composite sample. Two conditioning steps were performed. The initial conditioning step consisted of using fresh caustic corn starch at a concentration of 500 grams per ton (4\% starch, $1 \%$ sodium 
hydroxide, and $95 \%$ water mixed for one hour) and sodium silicate at a concentration of 300 grams per ton $\left(\mathrm{Na}_{3} \mathrm{SiO}_{3}\right)$ for 5 minutes.

The second conditioning step consisted of using fatty acid and collector at a concentration of 1,200 grams per ton and glycol frother for 5 minutes. Phosphate rougher concentrate was collected for 4 minutes, filtered, dried, and analyzed.

An additional conditioning step was performed for the phosphate scavenger concentrate. This consisted of fresh caustic corn starch $(500 \mathrm{~g} / \mathrm{t})$, sodium silicate $(200$ $\mathrm{g} / \mathrm{t})$, fatty acid and collector $(300 \mathrm{~g} / \mathrm{t})$, and glycol frother for 2 minutes. After conditioning, scavenger concentrate was collected for four minutes. Both the scavenger concentrate and tails sample were filtered, dried, and analyzed.

Mass balance results are shown in Tables 4 through 7 . Figure 1 illustrates the composite material flotation testing flowsheet.

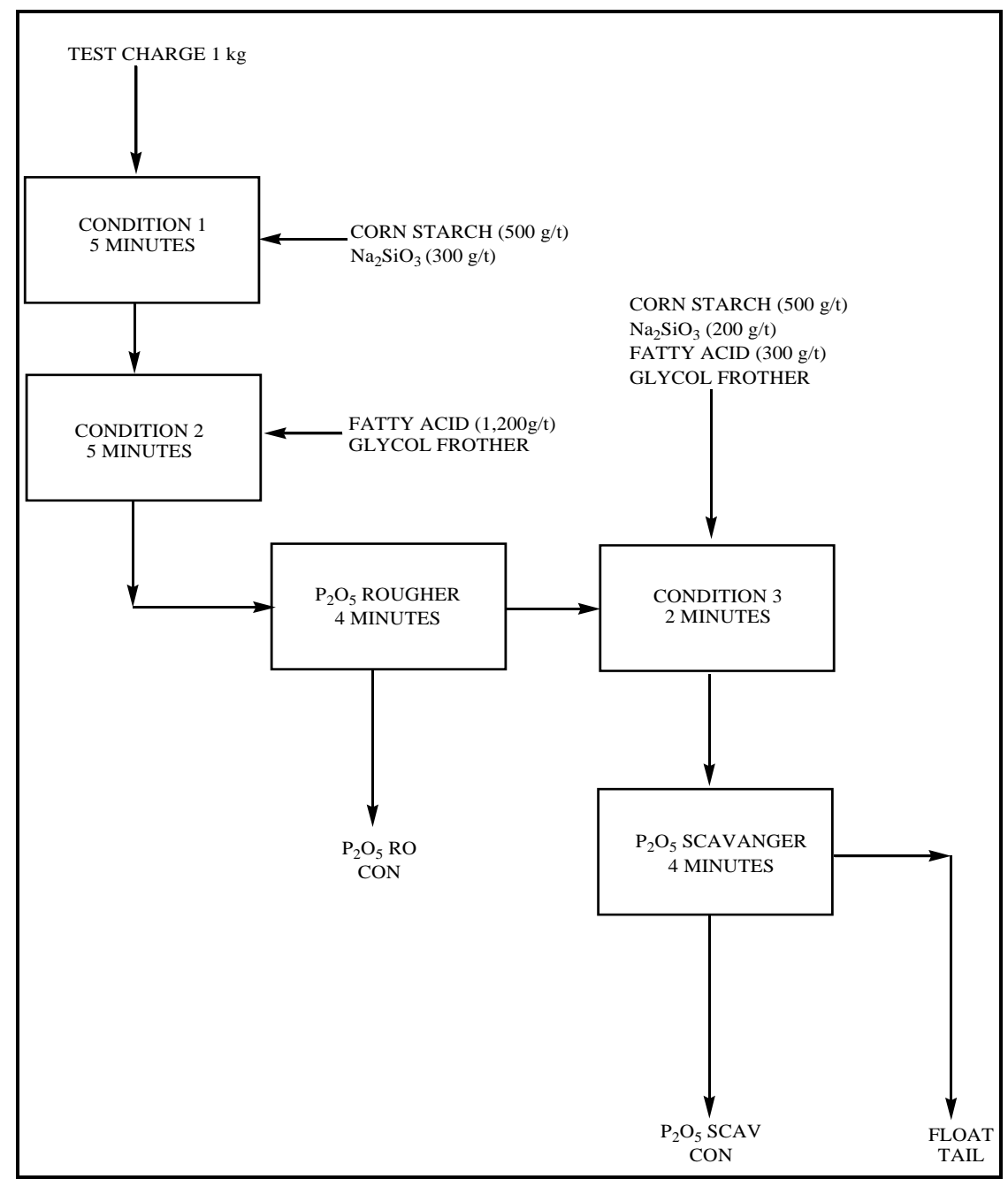

Fig. 1. Composite Flotation Testing Flowsheet. 
Table 4. Mass Balance of Fatty Acid/Tall Oil Flotation.

\begin{tabular}{lllllllllll}
\hline Product & \multicolumn{2}{c}{ Weight } & \multicolumn{4}{c}{ Assays, \% } & \multicolumn{3}{c}{ Distribution, \% } \\
& $\mathrm{g}$ & $\%$ & $\mathrm{Ce}$ & $\mathrm{P}$ & $\mathrm{Si}$ & $\mathrm{Fe}$ & $\mathrm{Ce}$ & $\mathrm{P}$ & $\mathrm{Si}$ & $\mathrm{Fe}$ \\
\hline Rougher Con & 294.4 & 30.31 & 1.41 & 8.03 & 5.44 & 3.51 & 62.59 & 78.10 & 10.94 & 23.40 \\
Scav Con & 18.5 & 1.90 & 1.21 & 11.07 & 8.32 & 1.49 & 3.36 & 6.76 & 1.05 & 0.62 \\
Tails & 658.4 & 67.79 & 0.34 & 0.70 & 19.56 & 5.10 & 34.05 & 15.13 & 88.00 & 75.98 \\
Calc. Head & 971.3 & 100 & 0.68 & 3.12 & 15.07 & 4.55 & 100 & 100 & 100 & 100 \\
Assay Head & & & 0.67 & 3.07 & 15.66 & 4.86 & & & & \\
\hline
\end{tabular}

Table 5. Mass Balance of Fatty Acid/Tall Oil Flotation.

\begin{tabular}{|c|c|c|c|c|c|c|c|c|c|}
\hline \multirow[t]{2}{*}{ Product } & \multirow{2}{*}{$\begin{array}{l}\text { Weight } \\
\%\end{array}$} & \multicolumn{4}{|c|}{ Assays, $\%$ or g Au /t } & \multicolumn{4}{|c|}{ Distribution, $\%$} \\
\hline & & $\mathrm{Ce}$ & $\mathrm{P}$ & $\mathrm{Si}$ & $\mathrm{Fe}$ & $\mathrm{Ce}$ & $\mathrm{P}$ & $\mathrm{Si}$ & $\mathrm{Fe}$ \\
\hline Rough Con & 30.31 & 1.41 & 8.03 & 5.44 & 3.51 & 62.5 & 78.10 & 10.94 & 23.40 \\
\hline Ro + Scav Con & 32.21 & 1.40 & 8.21 & 5.61 & 3.39 & 65.9 & 84.87 & 12.00 & 24.02 \\
\hline
\end{tabular}

Table 6. Mass Balance of Fatty Acid/Petroleum Sulfonate Flotation.

\begin{tabular}{lllllllllll}
\hline Product & \multicolumn{2}{c}{ Weight } & \multicolumn{4}{c}{ Assays, \% } & \multicolumn{2}{c}{ Distribution, \% } & \\
& $\mathrm{g}$ & $\%$ & $\mathrm{Ce}$ & $\mathrm{P}$ & $\mathrm{Si}$ & $\mathrm{Fe}$ & $\mathrm{Ce}$ & $\mathrm{P}$ & $\mathrm{Si}$ & $\mathrm{Fe}$ \\
\hline Rougher Con & 304.3 & 31.57 & 0.86 & 6.26 & 13.54 & 2.18 & 42.67 & 61.18 & 28.27 & 14.36 \\
Scav Con & 114.1 & 11.84 & 1.49 & 6.05 & 10.74 & 1.61 & 27.67 & 22.17 & 8.41 & 3.97 \\
Tails & 545.6 & 56.60 & 0.34 & 0.95 & 16.92 & 6.90 & 29.66 & 16.65 & 63.33 & 81.67 \\
Calc. Head & 964.0 & 100 & 0.64 & 3.23 & 15.12 & 4.78 & 100 & 100 & 100 & 100 \\
Assay Head & & & 0.67 & 3.07 & 15.66 & 4.86 & & & & \\
\hline
\end{tabular}

Table 7. Mass Balance of Fatty Acid/Petroleum Sulfonate Flotation.

\begin{tabular}{llllllllll}
\hline Product & Weight & \multicolumn{3}{c}{ Assays, \% or $\mathrm{g} \mathrm{Au} / \mathrm{t}$} & \multicolumn{5}{c}{ Distribution, \% } \\
& $\%$ & $\mathrm{Ce}$ & $\mathrm{P}$ & $\mathrm{Si}$ & $\mathrm{Fe}$ & $\mathrm{Ce}$ & $\mathrm{P}$ & $\mathrm{Si}$ & $\mathrm{Fe}$ \\
\hline $\begin{array}{l}\text { Rough Con } \\
\text { Ro + Scav }\end{array}$ & 31.57 & 0.86 & 6.26 & 13.54 & 2.18 & 42.6 & 61.18 & 28.27 & 14.36 \\
Con & 43.40 & 1.04 & 6.20 & 12.78 & 2.02 & 70.3 & 83.35 & 36.67 & 18.33 \\
\hline
\end{tabular}

Results from the flotation work of composite were like earlier testing on the bulk composite. For fatty acid/fuel oil, $65.9 \%$ of the cerium reported to the rougher and scavenger while previous tests, $69.1 \%$ of the cerium reported to the concentrates. Correspondingly, almost $85 \%$ of phosphate reported to concentrates. Previous flotation results had shown almost $100 \%$ recovery of phosphate from the bulk composite.

For fatty acid/petroleum sulfonate, flotation results were like previous composite testing. $70.3 \%$ of the cerium reported to the concentrates while previous work indicated $67.3 \%$ recovery. $83.35 \%$ of phosphorous reported to concentrates. Again, bulk flotation had shown nearly $100 \%$ removal of phosphate from TREO material.

While these flotation results are encouraging, prudent engineering practice would suggest that optimization followed by locked cycle testing is necessary. 


\section{Heavy liquid separation}

Further composite testing was carried out using heavy media separation. For the testing, specific gravity solutions of $2.9,3.0,3.1,3.2,3.3,3.4$, and 3.5 were made. Approximately 100 grams of composite sample was placed into the solution and allowed to mix for 5 minutes. The solution was then allowed to separate for 30 minutes. According to fundamentals, particles with a lower specific gravity of the solution should float while particle with higher specific gravity than the solution will fall. Sample floats, mids, and sinks were collected, filtered, dried, and analyzed. The results of heavy media separation testing are shown in Figures 2 through 4.

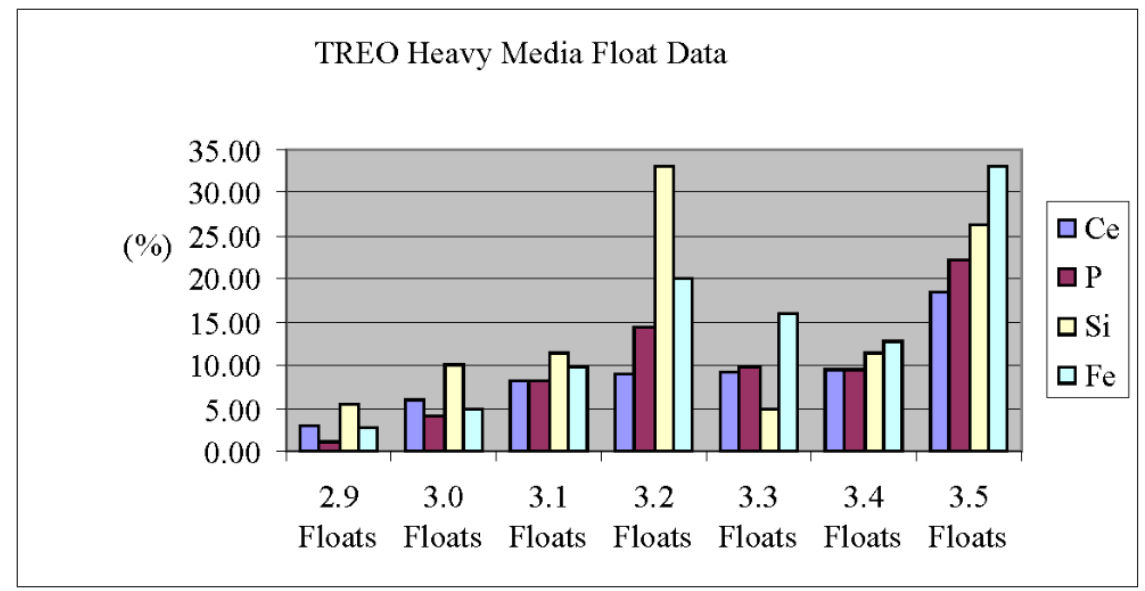

Fig. 2. Heavy Media Float Recovery \% Data.

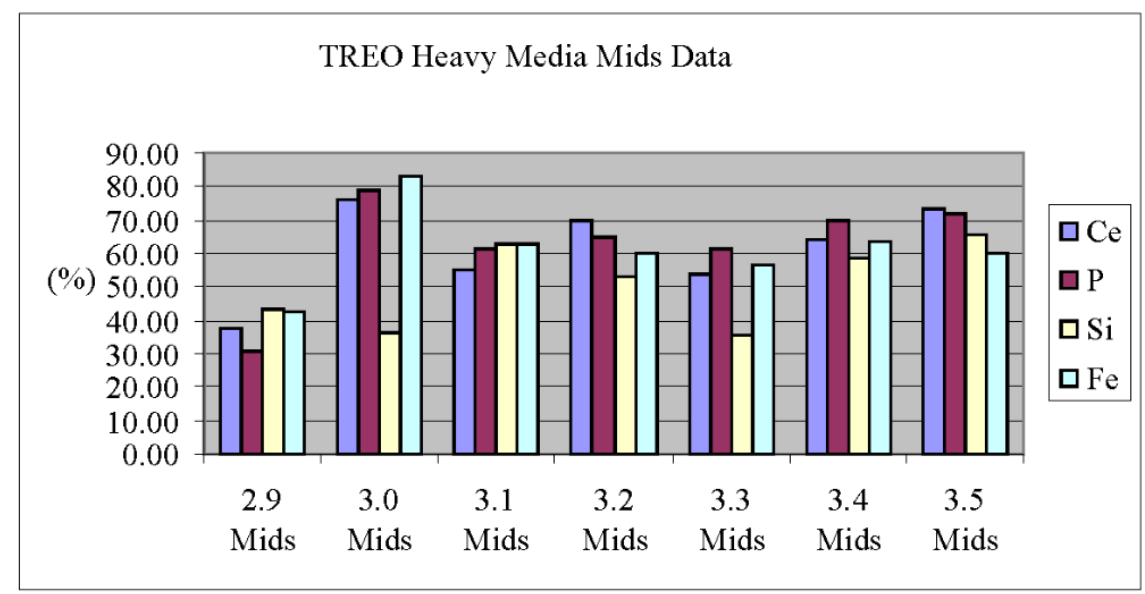

Fig. 3. Heavy Media Mids Recovery \% Data. 


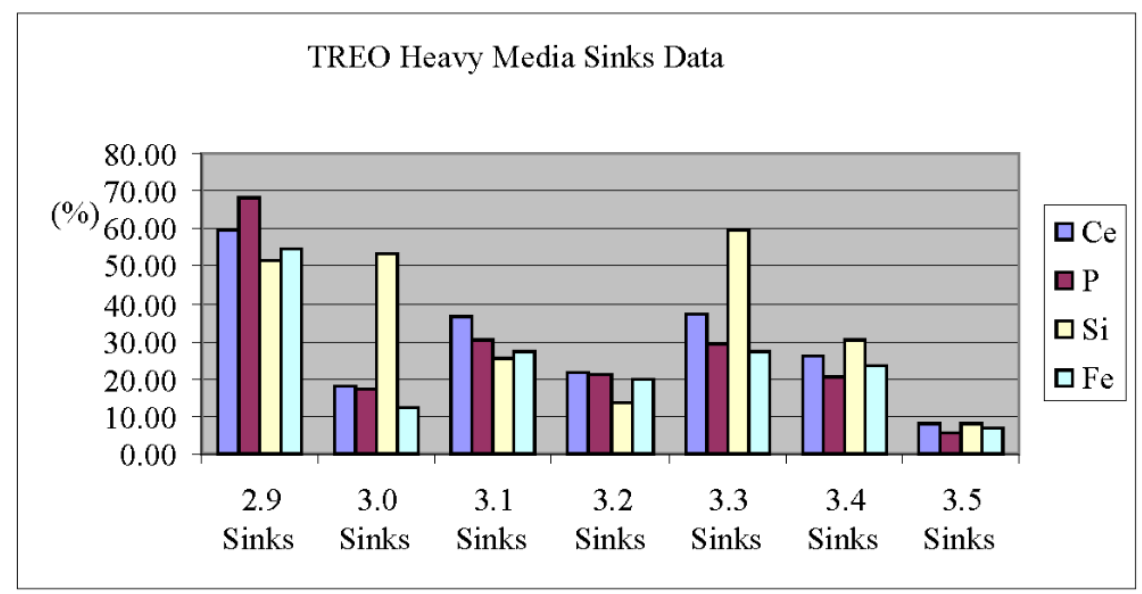

Fig. 4. Heavy Media Sinks Recovery \% Data.

According to the data, the best parameter for phosphorous recovery occurred at 2.9 specific gravity with a collection of the sinks. Almost $70 \%$ of the phosphorous was successfully recovered. This would concur with heavy media separation of apatite. Because the specific gravity of apatite is 3.1 to 3.2 , the best results achieved would occur at sinks at the lowest parameter or floats at the highest parameter. For float data, the best results occur at a specific gravity of 3.5 and almost $25 \%$ of the phosphorous was successfully removed.

For cerium, the best results occurred in sinks at a 2.9. Since cerium has two potential phases, allanite and allanite, with specific gravities of 3.0-4.2 and 3.1-3.2 respectively, the best results should occur in the sinks of the lowest tested specific gravity solution. According to the results, almost $60 \%$ of cerium was successfully recovered.

Finally, when heavy media separation is done, the specific gravity of the known required mineral from other minerals should be greater than one. Allanite minerals have a wide range of specific gravity of 3.0 to 4.2 and apatite minerals have a specific gravity of 3.1 to 3.2. Hence, a lower and wider density of solution should be tested if heavy media separation is going to be pursued further. For future testing, solutions with specific gravities of $1.5,2.0$, and 2.5 should be evaluated.

\section{Whole material leaching}

For the leaching study of whole TREO material, used a STAT-EASE software package. Five variables were chosen to maximize leaching parameters and included reaction time (4 to 8 hours), reaction temperature $(25$ to $55 \mathrm{C}$ ), acidity or alkalinity equivalent strength, percent solids (10 to 20), and mesh size (100 to 200). From these variables, a quarter matrix, along with 3 replicates, using the software package was designed for hydrochloric acid and sulfuric acid of whole TREO material.

The experimental design matrix used in the study was developed using STATEASE software. The design used was a 2-level $1 / 4$-factorial design matrix. The matrices and experimental results are presented in Tables 8 through 11 . 
Table 8. Design Matrix for HCl Acid Leaching

\begin{tabular}{lccccc}
\hline $\begin{array}{l}\text { Matrix Standard } \\
\text { Run Number }\end{array}$ & $\begin{array}{c}\text { Time } \\
\text { Hrs }\end{array}$ & $\begin{array}{c}\text { Temp } \\
{ }^{\circ} \mathrm{C}\end{array}$ & $\begin{array}{c}\mathrm{HCl} \\
\mathrm{g} / \mathrm{kg} \text { material }\end{array}$ & \%Solids & $\begin{array}{c}\text { Mesh } \\
\text { Size }\end{array}$ \\
\hline 7 & 4 & 55 & 300 & 10 & 100 \\
11 & 6 & 40 & 200 & 15 & 150 \\
8 & 8 & 55 & 300 & 20 & 200 \\
9 & 6 & 40 & 200 & 15 & 150 \\
10 & 6 & 40 & 200 & 15 & 150 \\
6 & 8 & 25 & 300 & 10 & 200 \\
2 & 8 & 25 & 100 & 10 & 100 \\
1 & 4 & 25 & 100 & 20 & 200 \\
3 & 4 & 55 & 100 & 10 & 200 \\
4 & 8 & 55 & 100 & 20 & 100 \\
5 & 4 & 25 & 300 & 20 & 100 \\
\hline
\end{tabular}

Table 9. Design Matrix Experimental Results for HCl Leaching.

\begin{tabular}{lcc}
\hline $\begin{array}{l}\text { Matrix Standard } \\
\text { Run Number }\end{array}$ & \multicolumn{2}{l}{ Response } \\
Element & Recovery, \% \\
\hline & Cerium & Phosphorus \\
\cline { 2 - 3 } 7 & 60.5 & 62.2 \\
11 & 22.0 & 26.7 \\
8 & 34.5 & 40.4 \\
9 & 33.8 & 36.9 \\
10 & 45.6 & 32.7 \\
6 & 71.1 & 59.9 \\
2 & 72.0 & 58.6 \\
1 & 55.0 & 29.8 \\
3 & 81.0 & 62.2 \\
4 & 53.7 & 41.0 \\
5 & 42.0 & 30.8 \\
\hline
\end{tabular}

Table 10. Design Matrix for $\mathrm{H}_{2} \mathrm{SO}_{4}$ Acid Leaching.

\begin{tabular}{lccccc}
\hline $\begin{array}{l}\text { Matrix Standard } \\
\text { Run Number }\end{array}$ & $\begin{array}{c}\text { Time } \\
\mathrm{Hrs}\end{array}$ & $\begin{array}{c}\mathrm{Temp} \\
{ }^{\circ} \mathrm{C}\end{array}$ & $\begin{array}{c}\mathrm{H}_{2} \mathrm{SO}_{4} \\
\text { g/kg material }\end{array}$ & \% Solids & $\begin{array}{c}\text { Mesh } \\
\text { Size }\end{array}$ \\
\hline 6 & 8 & 25 & 114 & 10 & 200 \\
8 & 8 & 55 & 114 & 20 & 200 \\
10 & 6 & 40 & 76 & 15 & 150 \\
9 & 6 & 40 & 76 & 15 & 150 \\
4 & 8 & 55 & 38 & 20 & 100 \\
2 & 8 & 25 & 38 & 10 & 100 \\
7 & 4 & 55 & 114 & 10 & 100 \\
1 & 4 & 25 & 38 & 20 & 200 \\
3 & 4 & 55 & 38 & 10 & 200 \\
11 & 6 & 40 & 76 & 15 & 150 \\
5 & 4 & 25 & 114 & 20 & 100 \\
\hline
\end{tabular}


Table 11. Design Matrix Experimental Results for $\mathrm{HCl}$ Leaching.

\begin{tabular}{lcc}
\hline Matrix Standard & \multicolumn{2}{c}{ Response } \\
Run Number & Element Recovery, \% \\
\hline & Cerium & Phosphorus \\
\cline { 2 - 3 } 6 & 52.8 & 56.4 \\
8 & 23.3 & 29.6 \\
10 & 43.7 & 45.8 \\
9 & 76.8 & 49.3 \\
4 & 39.6 & 32.9 \\
2 & 50.4 & 68.1 \\
7 & 51.0 & 54.7 \\
1 & 27.1 & 38.9 \\
3 & 95.0 & 75.2 \\
11 & 61.2 & 50.4 \\
5 & 47.3 & 38.3 \\
\hline
\end{tabular}

\section{STATEASE Evaluation for Cerium Recovery by Hydrochloric Leaching}

The statistical evaluation results show that the only significant variables are percent solids and $\mathrm{HCl}$ acid concentration (however, each of these variables may also include interactive effects).

Low percent solids and low $\mathrm{HCl}$ acid concentration favor cerium recovery (detailed STATEASE results are presented in the appendices). The effects of the variables are summarized in Figure 5.

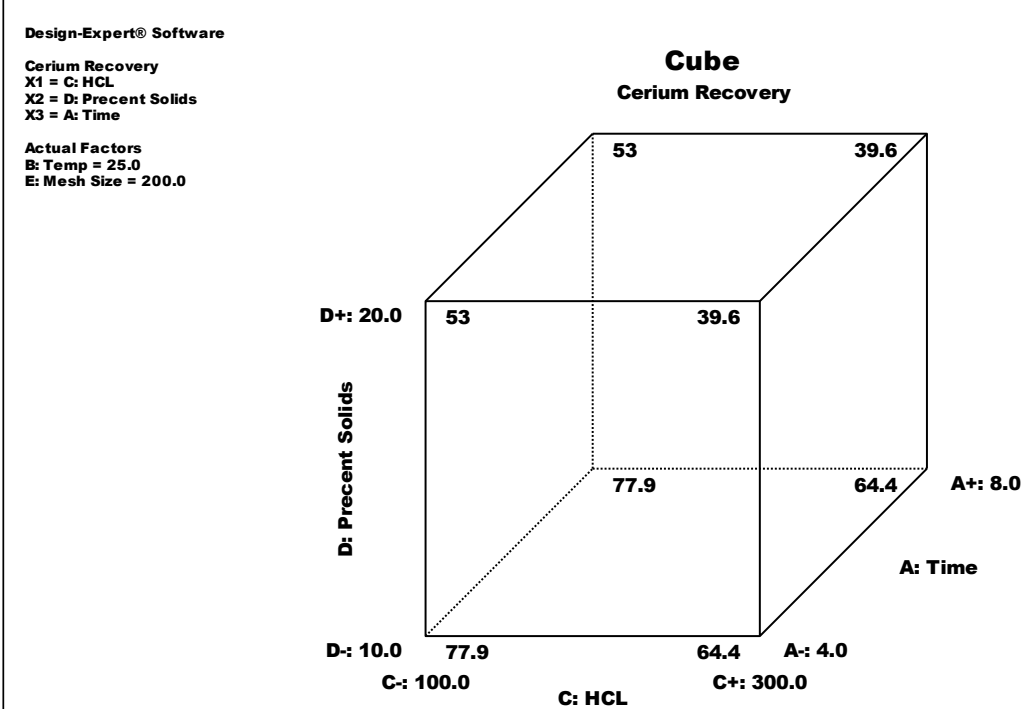

Fig. 5. The Influence of Variables on the Recovery of Cerium by HCl Leaching. 
STATEASE Evaluation for Phosphate Recovery by Hydrochloric Leaching

The statistical evaluation results show that the variables percent solids (most important) and temperature favor phosphate recovery.

Overall, the best conditions for the recovery of cerium (low percent solids, low $\mathrm{HCl}$ concentrations where temperature and mesh size were relatively unimportant) should yield approximately fifty percent recovery of phosphate.

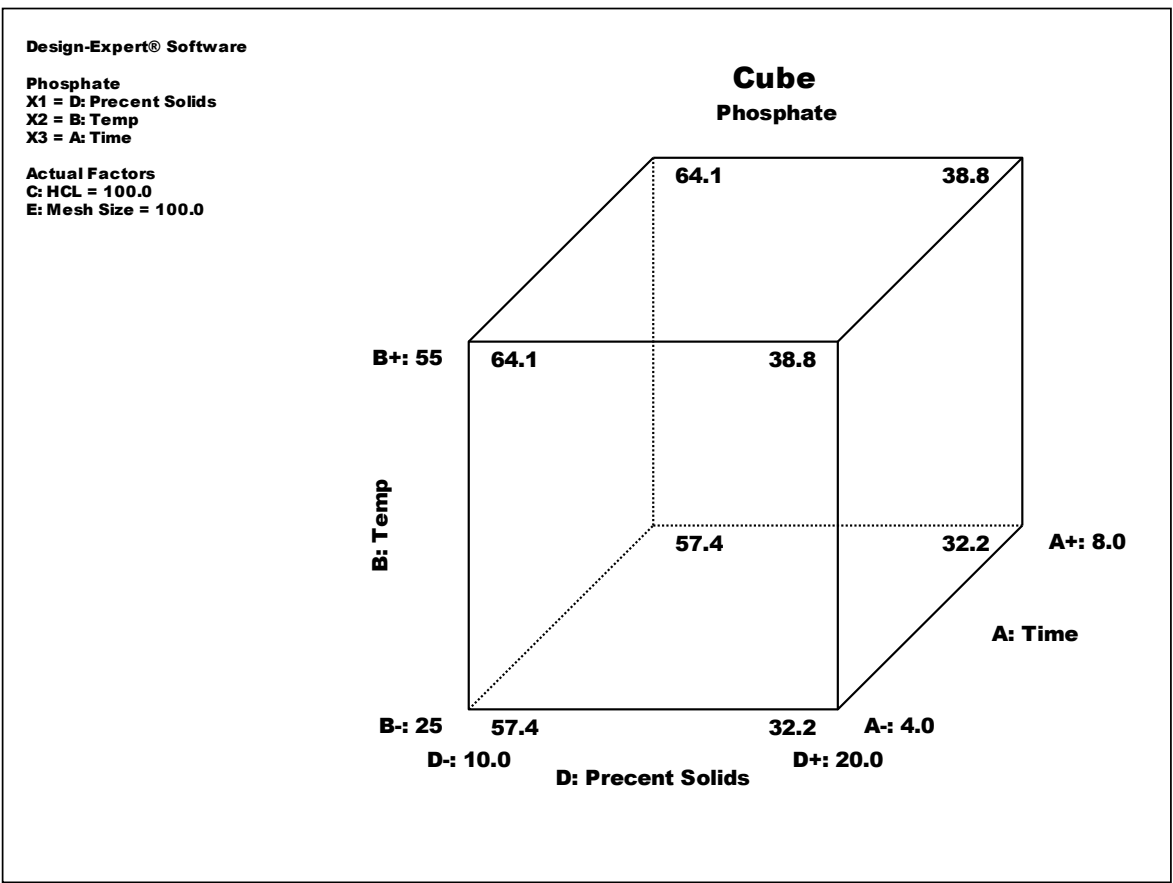

Fig. 6. The Influence of Variables on the Recovery of Phosphate by HCl Leaching.

\section{STATEASE Evaluation for Cerium Recovery by Sulfuric Acid Leaching}

The statistical evaluation results show that the only significant variables are \% solids and the interaction between temperature and sulfuric acid content (however, each of these variables may also include other interactive effects). The effects of the variables are summarized in Figure 7.

The best recovery of cerium occurs at low percent solids, low temperature, high acid content, short time, and small mesh size. Note that even though mesh size does not show up as an important variable in the statistical analysis, the interactive effects that are also included in the mesh size variable cause the mesh size variable to appear to be important. 


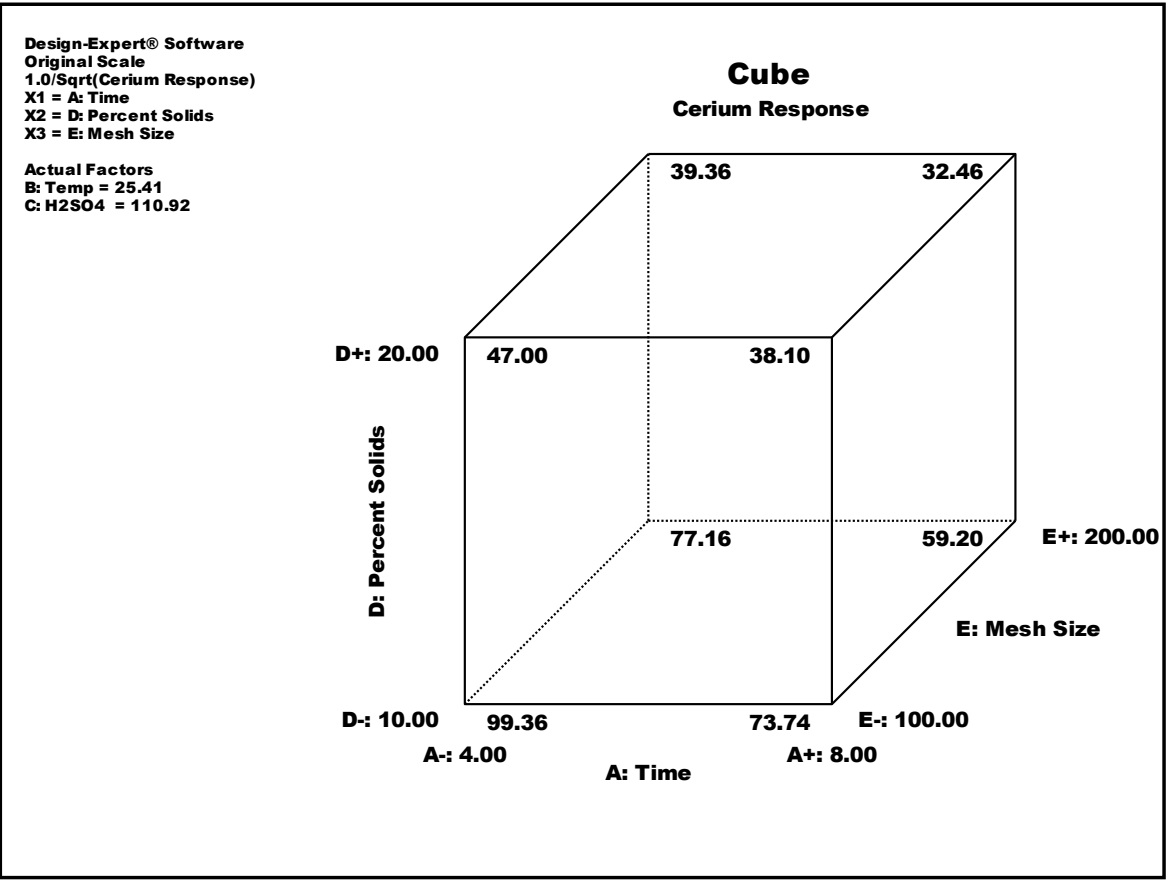

Fig. 7. The Influence of Variables on the Recovery of Cerium by Sulfuric Acid Leaching.

STATEASE Evaluation for Phosphate Recovery by Sulfuric Acid Leaching

The statistical evaluation results show that the significant factors are percent solids (most important), acid concentration, and the interaction between temperature and size. The effects of the variables are summarized in Figure 8.

The best recovery occurs at low temperature, low acid content, low percent solids, and small mesh size. 


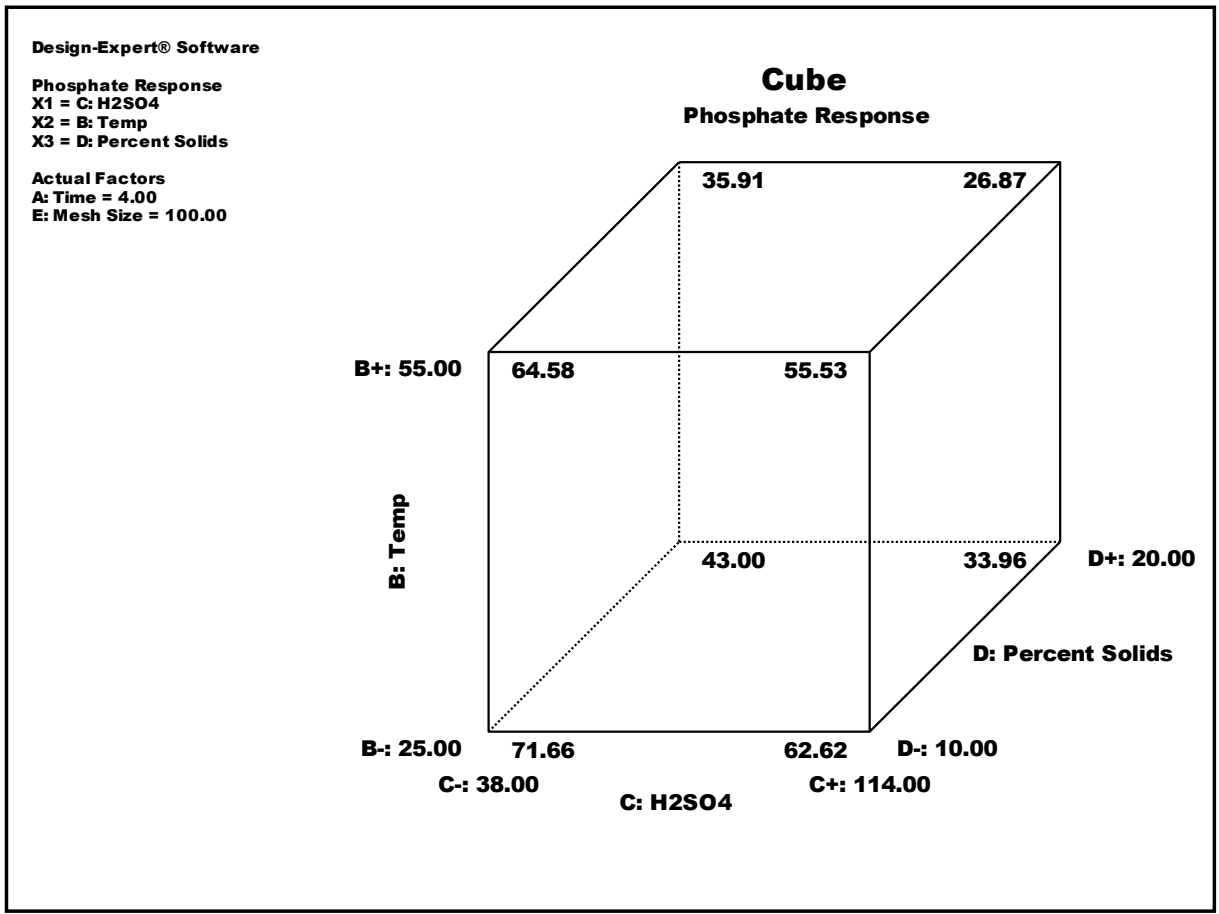

Fig. 8. The Influence of Variables on the Recovery of Phosphate by Sulfuric Acid Leaching.

The Comparison Between Hydrochloric and Sulfuric Acid Leaching

A comparison of the recovery of cerium using hydrochloric and sulfuric acid is presented in Table 12.

Table 12. Comparison of achievable cerium and phosphate recovery results using either hydrochloric or sulfuric acid.

\begin{tabular}{llc}
\hline & \multicolumn{2}{l}{ Final Element } \\
Recovery, \% \\
Ce & $\mathrm{P}$ \\
\hline $\begin{array}{l}\text { Maximum recovery of Ce using } \mathrm{HCl} \text { : low } \mathrm{HCl}(100 \mathrm{~g} / \mathrm{kg} \\
\text { material), low temp, low \% solids, low mesh size }\end{array}$ & 78 & 57 \\
$\begin{array}{l}\text { Maximum recovery of Ce using } \mathrm{H}_{2} \mathrm{SO}_{4} \text { : high } \mathrm{H}_{2} \mathrm{SO}_{4}(114 \mathrm{~g} / \mathrm{kg} \\
\text { material), low temp, low \% solids, low mesh size }\end{array}$ & 103 & 63 \\
\hline
\end{tabular}

\section{Caustic Cracking}

Sodium hydroxide (Caustic) cracking was also evaluated using the STAT-EASE matrix. Test parameters and results are shown in Tables 13 and 14. 
Table 13. Design Matrix for Caustic Cracking.

\begin{tabular}{lccccc}
\hline $\begin{array}{c}\text { Matrix Standard } \\
\text { Run Number }\end{array}$ & $\begin{array}{c}\text { Time } \\
\text { Hrs }\end{array}$ & $\begin{array}{c}\text { Temp } \\
{ }^{\circ} \mathrm{C}\end{array}$ & $\begin{array}{c}\text { NaOH } \\
\text { g/kg material }\end{array}$ & \%Solids & $\begin{array}{c}\text { Mesh } \\
\text { Size }\end{array}$ \\
\hline 4 & 8 & 55 & 35 & 20 & 100 \\
6 & 8 & 25 & 104 & 10 & 200 \\
9 & 6 & 40 & 69.5 & 15 & 150 \\
11 & 6 & 40 & 69.5 & 15 & 150 \\
2 & 8 & 25 & 35 & 10 & 100 \\
1 & 4 & 25 & 35 & 20 & 200 \\
5 & 4 & 25 & 104 & 20 & 100 \\
7 & 4 & 55 & 104 & 10 & 100 \\
3 & 4 & 55 & 35 & 10 & 200 \\
10 & 6 & 40 & 69.5 & 15 & 150 \\
8 & 8 & 55 & 104 & 20 & 200 \\
\hline
\end{tabular}

Table 14. Design Matrix Experimental Results for Caustic Cracking.

\begin{tabular}{lcc}
\hline $\begin{array}{l}\text { Matrix Standard } \\
\text { Run Number }\end{array}$ & \multicolumn{2}{c}{ Response } \\
Element Recovery, \% \\
\hline & Aluminum & Silicon \\
\cline { 2 - 3 } 4 & 1.48 & 0.80 \\
6 & 1.39 & 0.69 \\
9 & 1.94 & 1.05 \\
11 & 2.91 & 1.27 \\
2 & 3.39 & 1.65 \\
1 & 1.27 & 0.78 \\
5 & 1.51 & 0.80 \\
7 & 7.53 & 4.11 \\
3 & 4.23 & 3.08 \\
10 & 2.09 & 1.54 \\
8 & 2.13 & 1.49 \\
\hline
\end{tabular}

Based on this, caustic cracking has no effect on the removal of rare earth elements, and minimal effect on removal of aluminum, or silicon. Because of the poor results, further STAT-EASE evaluation of data was not completed.

\section{Magnetic separation}

Magnetic separation test work was completed on the TREO composite. Two mesh sizes, 50 and 100, were evaluated using a two stage separation technique. The test samples were subjected to a wet high intensity magnetic separation at a field strength of 5,000 gauss. This step produces both a magnetic and non magnetic fraction. The non magnetic fraction was further testing using a magnetic field strength of 8,000 gauss. This step produced both a magnetic and final non magnetic product. Both magnetic and non magnetic fractions have been sent for ICP analysis. The results of both tests are shown in Figures 9 and 10 and Table 15. 


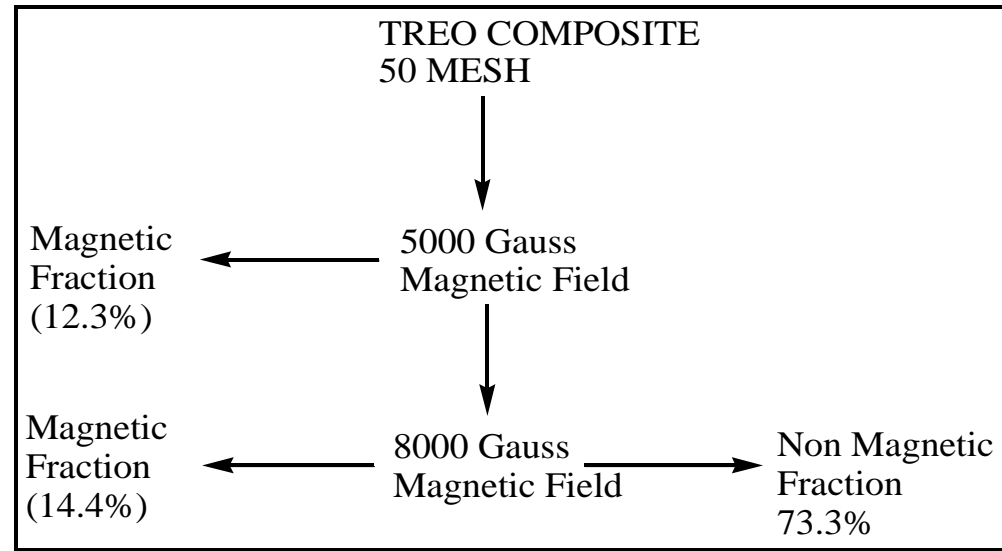

Fig. 9. TREO 50 Mesh Magnetic Separation Results.

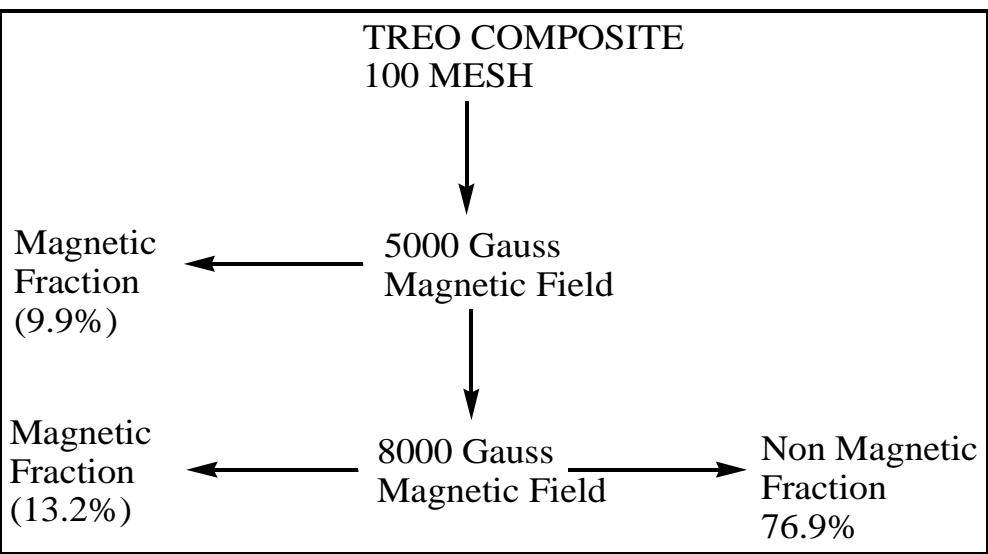

Fig. 10. TREO 100 Mesh Magnetic Separation Results.

Table 15. Magnetic Separation Results

\begin{tabular}{llll}
\hline Sample & 5,000 Mag Fraction & 8,000 Mag Fraction & Non Mag Fraction \\
\hline 50 Mesh & $12.3 \%$ & $14.4 \%$ & $73.3 \%$ \\
100 Mesh & $9.9 \%$ & $13.2 \%$ & $76.9 \%$ \\
\hline
\end{tabular}

\section{Bond work index and relative abrasion index}

A bond grindability work index was performed on the TREO material composite. Results indicate that $13.56 \mathrm{Kw} \mathrm{Hr} / \mathrm{Ton}$ are required to successfully grind 6 mesh TREO material to 80 percent passing of 200 mesh. Bond work index results indicate the TREO material is considered to have a medium grindability.

For the relative abrasion index, the calculation using chemical analysis yielded an abrasion index of 0.120 . From this index, the TREO material is considered relatively non abrasive for practical purposes. 


\section{Summary}

Results from flotation work of composite were like earlier testing on another bulk material composite. For fatty acid/fuel oil based flotation, $65.9 \%$ of the cerium reported to the rougher and scavenger concentrates. In previous tests, $69.1 \%$ of cerium reported to the concentrates. For phosphorous recovery, almost $85 \%$ of phosphate reported to concentrates. Previous flotation results had shown almost $100 \%$ recovery of the phosphate from a bulk composite.

For fatty acid/petroleum sulfonate flotation, results were like previous composite material sample testing. $70.3 \%$ of the cerium reported to the concentrates while previous work indicated $67.3 \%$ cerium recovery. In addition, $83.35 \%$ of the phosphorous reported to the concentrates. Previous, flotation had shown nearly $100 \%$ recovery of phosphate from a bulk composite.

While these results are encouraging, prudent engineering practice would necessitate optimization followed by locked cycle confirmatory testing.

Further testing was conducted using heavy media separation on the new composite. For this specific gravity solutions of 2.9, 3.0, 3.1, 3.2, 3.3, 3.4, and 3.5 were used.

Based on this, the best parameter for phosphorous recovery occurred at 2.9 S.G. with collection of TREO sinks. Almost $70 \%$ of the phosphorous was successfully recovered. For float data, the best results occurred at of 3.5 S.G. and with $25 \%$ of phosphorous successfully removed. For cerium, the best results occurred in the sinks at a 2.9 S.G. For future testing, solutions with specific gravities of 1.5, 2.0, and 2.5 S.G. respectively should be evaluated.

For the leaching study of whole TREO material, a STAT-EASE DOE software package was used. This minimizes client time and cost while maximizing results and delineating variable interactions. Five variables were chosen to study leaching of cerium and phosphate. These variables included reaction time ( 4 to 8 hours), reaction temperature ( 25 to $55 \mathrm{C}$ ), acidity or alkalinity equivalent strength, percent solids (10 to 20), and mesh size (100 to 200). With these variables, a quarter design matrix, along with 3 replicates, was designed and utilized for hydrochloric acid, sulfuric acid, and caustic leaching of the TREO material composite.

For hydrochloric acid leaching, the best conditions for the maximum leaching of cerium are low percent solids and low acid concentration. Based on the model, these best conditions should recover $80 \%$ cerium and approximately $50 \%$ phosphate.

For sulfuric acid leaching, the statistical evaluation results show that the only significant variables are percent solids and the interaction between temperature and sulfuric acid content (however, each of these variables may also include other interactive effects).

Results of sulfuric acid leaching indicate the best recovery of cerium occurs at low percent solids, low temperature, high acid content, short time, and small mesh size.

For recovery of phosphate using sulfuric acid leaching, the best recovery occurs at low temperature, low acid content, low \% solids, and small mesh size. Based on the model, these conditions should recover $95 \%$ cerium and approximately $65 \%$ phosphate.

Overall, an equivalent comparison of the Stat Ease DOE based hydrochloric acid and sulfuric acid leach testing results indicates superior recoveries of cerium and phosphate with the use of sulfuric acid. Fortunately, neither acid under the conditions tested showed any formation or deleterious effects from the formation of silica gels. 
Caustic cracking testing has no effect on the removal of rare earth elements and little effect on aluminum, or silicon. Because of the poor results, further STAT-EASE evaluation of the data was not completed.

Magnetic separation test work was completed on the TREO material composite. Two mesh sizes, 50 and 100, were evaluated using a two stage separation technique. Both magnetic and non magnetic fractions are undergoing ICP analysis.

A bond work index test was performed on the composite. Results indicate that 13.56 Kw $\mathrm{Hr} /$ Ton are required to successfully grind 6 mesh to 80 percent passing of 200 mesh. The Bond work index results indicate the material is of medium grindability.

For the relative abrasion index, the calculation using chemical analysis yielded an abrasion index of approximately 0.120 . From this index, the TREO material is considered relatively non abrasive for practical purposes. Comprehensive testing should be done to confirm this.

\section{References}

[1] K. Pandur, Kevin M. Ansdell, Daniel J. Kontak, Kimberley M. Halpin, and Steven Creighton: Economic Geology ,111 (2016) 667-694.

[2] U.S. Department of the Interior, U.S. Geological Survey, Critical Mineral Resources of the United States- Economic and Environmental Geology and Prospects for Future Supply, Edited by Klaus J. Schulz, John H. DeYoung, Jr., Robert R. Seal II, and Dwight C. Bradley, Professional Paper 1802, (2018)

[3] P. Keller, C.G. Anderson: Aspects in Mining and Mineral Science, 2 (2018) AMMS.000532.

[4] P. Keller, C.G. Anderson: Research and Development in Materials Science, 4 (2018) RDMS.000593.

[5] C.G. Anderson: Industrial Manufacture of By Product Critical Materials, Presented at the DOE CMI Annual Meeting, (2016).

[6] C.G. Anderson: The Critical Aspect of Critical Materials, Presented at the DOE CMI Webinar Series, (2016).

[7] R. Eggert, C. Wadia, C.G. Anderson, D. Bauer, F. Fields, L. Meinert, P. Taylor: Annual Review of Environment and Resources, 41 (2016) 10.1-10.24.

[8] D. Imholte, R. Nguyen, A. Vedantam, M. Brown, A. Iyer, J. Collins, R. Eggert, C. Anderson, B. O'Kelley: Energy Policy, 113 (2017) 294-305.

[9] C.D. Anderson, P. Taylor, C.G. Anderson: American Journal of Engineering Research, 6 (2017) 155-166.

[10] C.D. Anderson, P. Taylor, C.G. Anderson: Rare Earth Flotation Fundamentals: A Review; IMPC 2016 Proceedings of the XXVIII International Mineral Processing Congress, ISBN: 978-1-926872-29-2, (2016).

[11] C.D. Anderson: Improved Understanding of Rare Earth Surface Chemistry and its Application to Froth Flotation, KIEM PhD thesis, Colorado School of Mines, (2015).

[12] B. Kronholm, C. Anderson, P. Taylor: Journal of Metals,65 (2013) 1321-1326.

[13] B. Kronholm, C.G. Anderson: Upgrade of Yttrium in a Mixed Rare Earth Stream Using Iminodiacetic Acid Functionalized Resin, U.S. Patent 10,696,562, (2020)

[14] B. Kronholm, Upgrade of Yttrium in a Mixed Rare Earth Stream Using Iminodiacetic Acid Functionalized Resin, KIEM MSc thesis, Colorado School of Mines

[15] Y. Zhang, F. Gu, Z. Su, S. Liu, C. Anderson, T. Jiang: Metals, 10 (2020) 841. 
[16] D. Schriner, C. Anderson: Journal of Metallurgical Engineering, 4 (2015) 69-77.

[17] D. Schriner: Advanced Beneficiation of Bastnaesite ORE Through Centrifugal Concentration and Froth Flotation, KIEM MSc Thesis, Colorado School of Mines, (2015).

[18] C. Norgren: Physical Beneficiation of Bastnaesite, KIEM MSc Thesis, Colorado School of Mines (2018).

[19] D. Everly: The Evaluation of Selective Collectors for Bastnaesite Flotation, KIEM MSc Thesis, Colorado School of Mines, (2017).

[20] D. Everly, C.G. Anderson, S. Jansone-Popova, V. Bryantsev, B. Moyer: Flotation of Bastnaesite Ore Using Novel Collectors, Proceedings of CIM MetSoc Annual Meeting, (2020).

[21] N. Williams: Bastnaesite Beneficiation by Froth Flotation and Gravity Separation, KIEM MSc Thesis, Colorado School of Mines, (2018)

[22] C.L. Owens, G.R. Nash, K. Hadler, R.S. Fitzpatrick, C.G. Anderson, F. Wall: Advances in Colloid and Interface Science, 256 (2018) 152-162.

[23] Y. Zhang, C. Anderson: Journal of Sustainable Metallurgy, 3 (2016) 39-47.

[24] Y. Zhang, C. Anderson: Minerals Engineering, 100 (2016) 1-8.

[25] Zhang, Y., Froth Flotation of Xenotime, KIEM MSc Thesis, Colorado School of Mines (2016).

[26] J. Mushidi, C. Anderson: Journal of Sustainable Metallurgy, 3 (2017) 62-72.

[27] J. Mushidi: Surface Chemistry and Flotation Behavior of Monazite, Apatite, Ilmenite, Quartz, Rutile, and Zircon Using Octanohydroxamic Acid Collector, KIEM MSc Thesis, Colorado School of Mines (2016).

[28] H. Cui, C. Anderson: The Simulation and Preliminary Studies on Bear Lodge Ore Flotation", Conference: SME Annual Meeting, At Phoenix, Arizona, Volume: Plant Design Session (2016).

[29] H. Cui, C. Anderson: Part of the The Minerals, Metals \& Materials Series book series (MMMS), Extraction (2018) 2597-2608.

[30] H. Cui, C. Anderson: Minerals Engineering 110 (2017) 166-178.

[31] H. Cui, C. Anderson: Journal of Sustainable Metallurgy, 3 (2017) 48-61.

[32] H. Cui: Beneficiation of Rare Earth Element Bearing Ancylite KIEM MSc Thesis, Colorado School of Mines (2015).

[33] H. Cui, C. Anderson: Beneficiation of Ancylite, U.S. Patent 10,618,058, (2020)

[34] V. Vaccarezza, C. Anderson: Beneficiation and Leaching Study of Norra Karr Eudialyte Mineral, Proceedings of Rare Metals Technology 2018, TMS, (2018) 39-51.

[35] V. Vaccarezza: Beneficiation and Hydrometallurgical Treatment of Norra Karr Eudialyte Material, KIEM MSc Thesis, Colorado School of Mines, (2017)

[36] V. Vaccarezza, C. Anderson: Mining, Metallurgy and Exploration, 37 (2020) 3950 .

[37] C.L. Owens, G.R. Nash, K. Hadler, R.S. Fitzpatrick, C.G. Anderson, F. Wall: Advances in Colloid and Interface Science, 265 (2019) 14-28.

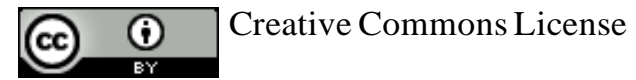

This work is licensed under a Creative Commons Attribution 4.0 International License. 